\title{
FASILITAS KEBUGARAN AKUATIK DI SUNTER
}

\author{
Arifia $^{1)}$, Lina Purnama ${ }^{2)}$ \\ 1) Program Studi S1 Arsitektur, Fakultas Teknik, Universitas Tarumanagara, arifia.fransisca@yahoo.com \\ 2) Program Studi S1 Arsitektur, Fakultas Teknik, Universitas Tarumanagara, linapurnama.112@gmail.com
}

\begin{abstract}
Abstrak
Salah satu isu kesejamanan kaum milenial yakni gaya hidup atau lifestyle kaum milenial yang tidak sehat karena tidak mampu mengendalikan gaya hidup mereka. Gaya hidup tersebut dipengaruhi oleh kemajuannya teknologi, pengaruh globalisasi seperti makanan cepat saji dan kemudahan pemenuhan kebutuhan seperti pelayanan antar berbasis aplikasi yakni ojek online dan features lainnya. Faktor-faktor tersebut secara langsung atau tidak langsung menyebabkan pola perilaku kaum Milenial menjadi tidak sehat, pasif (in-active), kondisi mental yang menurun, dan masih banyak lagi. Dengan begitu, perilaku tersebut memberikan banyak dampak negatif terhadap kondisi kesehatan jasmani dan rohani kaum milenial. Wellness berfokus pada dampak dari 'well-being' atau kesejahteraan individu. Menurut CDC (Centers for Disease Control dan Prevention), 'Well-being' dapat meningkatkan kesehatan jasmani dan rohani individu atau kelompok akibat hasil dari menjalani kehidupan dengan baik. Oleh karena itu, 'Wellness' dapat memberikan pergeseran terhadap gaya hidup menjadi lebih sehat dengan menghadirkan kesan menyenangkan dan menarik masyarakat terutama milenial yakni Fasilitas Kebugaran Akuatik. Unsur air dari segi akuatik memberikan relaksasi, ketenangan, suasana rekreasi yang dapat memberikan lingkungan menyenangkan untuk penyembuhan. Fasilitas kebugaran akuatik diberikan kesan rekreasi sehingga masyarakat maupun kaum milenial melakukan kegiatan kebugaran dengan perasaan senang. Untuk mendapatkan konsep program tersebut, penulis menggunakan kriteria wellness dari Tchiki Davis,PH.D. dan kuesioner yang menghasilkan program akuatik baik dari segi jasmani dan rohani serta kegiatan sosial dan perbaikan gaya hidup melalui monitoring habits. Konsep gubahan massa terbentuk dari 4 karakter unsur healing environment yakni air, batu, goa, dan gunung.
\end{abstract}

Kata kunci: akuatik; gaya hidup; milenial; wellness

\begin{abstract}
One of the contemporaneity issues of millenials is the lifestyle or millenial's unhealthy lifestyle because they are unable to control their lifestyle. These lifestyles are influenced by advances in technology that increase the influence of globalization such as fast food and ease of fulfillment of needs such as application-based inter-service namely online motorcycle taxi and other features. These factors directly or indirectly cause millennial's behavior patterns to be unhealthy, passive (in-active), decreased mental conditions, and much more. These behaviors have many negative effects on the physical and spiritual health conditions of millennials. Wellness aimed at the impact of 'well-being' or individual well-being. According to the CDC (Centers for Disease Control and Prevention), 'Well-being' can improve individuals or groups physical and spiritual health due to the results from who know how to live well. Therefore, 'Wellness' can provide a change towards a healthier lifestyle by presenting a pleasant and interesting impression of the mainly millennial community, the Aquatic Wellness Facility. The element of water from aquatic aspect provides relaxation, calmness, recreational atmosphere and so on that can provide a healing environment. Aquatic Wellness facilities are given the impression of recreation so that the community and millennials do physical activities with a feeling of pleasure. To get the concept of the program, the author uses the wellness criteria of Tchiki Davis, PH.D. and questionnaires that produce aquatic programs both in terms of physical and spiritual as well as social activities and lifestyle improvements through monitoring habits. The concept of mass composition is formed from 4 character elements of healing environment, namely water, stone, cave, and mountain.
\end{abstract}

Keywords: aquatic; lifestyle; millenial; wellness 


\section{PENDAHULUAN}

\section{Latar Belakang Proyek}

Zaman yang semakin maju ini di mana masyarakat kaum milenial kurang memperhatikan ataupun mengontrol gaya hidup dengan baik. Perilaku tersebut dapat menimbulkan masalah kesehatan baik jasmani dan rohani. Masalah kesehatan tersebut dipengaruhi juga oleh perkembangan teknologi. Dampak dari perkembangan teknologi tersebut juga dapat memicu frekuensi penggunaan media komunikasi terlalu sering, intensitas olahraga yang kurang, penyalahgunaan informasi dari media komunikasi, tidak mampu mengontrol pola makan seperti pengonsumsian makanan siap saji yang tidak sehat, dan seterusnya.

Kondisi tersebut menyebabkan kondisi kesehatan jasmani dan rohani menurun. Dari aspek jasmani, kondisi fisik akan menurun dikarenakan pola makan tidak sehat dengan intensitas olahraga yang kurang. Dari aspek rohani, kondisi masyarakat mengalami tuntutan hidup menyebabkan tingkat stres, depresi yang tinggi hingga penyalahgunaan informasi yang menghasilkan perilaku kriminalitas.

'Wellness' berfokus pada dampak 'well-being' atau kesejahteraan dari individu dan untuk mencari cara bagaimana ruang yang baik dikembangkan. 'Well-being' dapat meningkatkan kesehatan jasmani dan rohani akibat hasil positif dari individu atau kelompok yang mengetahui kehidupan mereka berjalan baik. Oleh karena itu, 'Wellness' dapat memberikan pergeseran terhadap gaya hidup menjadi lebih baik.

Visi proyek ini bertujuan untuk menyediakan wadah yang dapat memenuhi dan mengontrol kebiasaan yang mempengaruhi kesehatan lebih baik. Pengaruh tingginya frekuensi penggunaan media komunikasi, pengaruh globalisasi terhadap pemilihan makanan generasi milenial, dan seterusnya menjadi titik masalah dari gaya hidup masyarakat terutama milenial. Dengan demikian, wadah tersebut dapat meningkatkan kesehatan jasmani dan rohani masyarakat di zaman yang didominasi kaum milenial.

Beberapa dari misi yang akan dicapai yakni sebagai berikut:

a. Memicu pengeseran gaya hidup menjadi lebih baik dengan memberikan wadah untuk berkegiatan positif bagi jasmani dan rohani maupun memberikan kontribusi terhadap pola hidup masyarakat terutama kaum milenial

b. Memberikan pelayanan kesehatan yang baik dari sisi penanganan, pengetahuan, pembinaan, dan seterusnya.

Manfaat dari proyek 'Wellness' ini yakni meningkatkan motivasi diri dan perasaan senang, meningkatkan kesehatan mental, belajar mengatur gaya hidup dan memperhatikan lingkungan sekitar. Untuk mencapai hasil di mana terjadi peningkatan kualitas hidup setiap individu yang akan mempengaruhi peningkatan kualitas kehidupan kota. Perasaan senang, tujuan dan kepuasaan terhadap hidup menjadi kunci utama kesejahteraan masyarakat untuk menciptakan lingkungan yang sehat dan bugar.

\section{Urgensi Isu}

Milenial mudah terpengaruh dari unsur luar. Karakter tersebut menjadi kelemahan dari masyarakat saat ini maupun kaum milenial yang dapat menimbulkan masalah kesehatan. Berdasarkan artikel liputan6.com, Dr.Nadia Octavia mengatakan bahwa ada 4 masalah kesehatan yang rentan dialami generasi milenial yakni kurang aktif, obesitas, kurang mampu bersosialisasi dan seterusnya. Masalah kesehatan tersebut didukung juga dengan kemudahan dari teknologi komunikasi seperti penggunaan ojek online yang memberikan segala pelayanan di bidang jasa.

Pengaruh perkembangan teknologi yang diikuti dengan pergerakan globalisasi menyebabkan perilaku generasi milenial menjadi lebih bebas, meningkatnya kriminalitas, kecanduan dalam pemakaian teknologi terutama internet seperti kurang bersosialisasi secara langsung melainkan bersosialisasi melalui media sosial. Perilaku tersebut dapat 
memberikan pengaruh buruk bagi individual maupun umum dikarenakan individual tersebut telah mengalami penurunan kualitas hidup baik jasmani dan rohani. Dari pengaruh tersebut menyebabkan perilaku masyarakat terutama milenial menjadi tidak sehat.

\section{Pertanyaan Penelitian}

Pertanyaan penelitian ini adalah sebagai berikut :

a. Apa isu kesejamanan terhadap kesehatan yang akan mengancam masyarakat terutama kaum milenial pada tahun ke depan?

b. Apa solusi agar masyarakat terutama kaum milenial dapat terhindar dari dampak buruk gaya hidup yang pasif dan pemilihan makanan siap saji akibat pengaruh globalisasi dan kemajuan teknologi?

c. Apa solusi program desain kebugaran yang dapat menjawab isu kesejamanan bagi kaum milenial?

\section{Batasan Masalah}

Masalah dibatasi pada solusi, tanggapan, penyelesaian terhadap isu gaya hidup masyarakat terutama milenial untuk memberikan gaya hidup yang lebih sehat melalui fasilitas kebugaran akuatik.

\section{Tujuan Penelitian/Desain}

Tujuan penelitian/desain ini adalah sebagai berikut:

a. Mengetahui isu kesejamanan masalah kesehatan yang akan mengancam pada tahun ke depan

b. Mengetahui solusi agar masyarakat terutama kaum milenial dapat terhindar dari dampak buruk gaya hidup yang pasif dan pemilihan makanan siap saji akibat pengaruh globalisasi dan kemajuan teknologi

c. Mengetahui solusi program desain kebugaran yang dapat menjawab isu kesejamanan bagi kaum milenial

\section{KAJIAN LITERATUR}

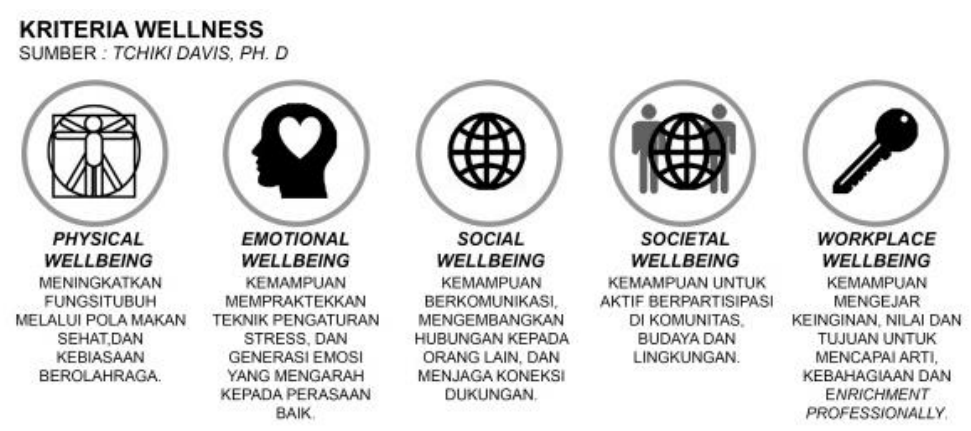

Gambar 1. Kriteria Wellness

Sumber: https://www. Psychologytoday.com, 2019

Berdasarkan Tchiki Davis, PH.D., terdapat 5 tipe 'Well-being' :

- Emotional Well-Being - Kemampuan mempraktekkan teknik pengaturan stress, dan generasi emosi yang mengarah ke perasaan baik.

- Physical Well-Being - Kemampuan meningkatkan fungsi tubuh melalui pola makan sehat, dan kebiasaan berolahraga.

- Social Well-Being - Kemampuan berkomunikasi, mengembangkan hubungan kepada orang lain, dan menjaga koneksi dukungan yang membantu menghadapi depresi atau kegelisahan. 
- Societal Well-Being - Kemampuan untuk aktif berpartisipasi di komunitas, budaya dan lingkungan.

- Workplace Well-Being - Kemampuan mengejar keinginan, nilai dan tujuan untuk mencapai arti, kebahagiaan dan enrichment professionally.

-

'Wellness' tersebut harus mengandung 5 tipe utama 'Well-being' untuk mencapai 'Wellbeing' secara keseluruhan. Jika individu atau kelompok merasa tidak senang, atau bahkan makan makanan tidak sehat, maka kehidupan individu atau kelompok akan terpengaruh dan merasa tidak sebaik yang diinginkan. Maka dari itu, 5 tipe utama 'Well-being' di atas harus saling berfungsi supaya kesejahteraan atau 'Well-being' tercapai.

Menurut Sternberg (2009:178), 4 unsur healing enviroment dari 4 universal symbols yakni air, batu, gunung-plus goa dan keindahan dari spot yang dapat membantu individu atau kelompok untuk dapat sembuh.

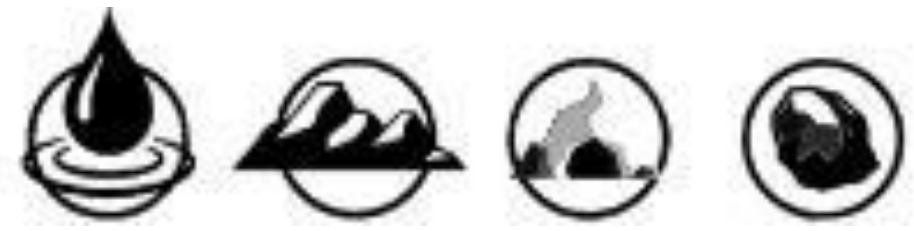

Gambar 2. unsur healing environment

Sumber: Sternberg, 2009

4 unsur healing environment yakni air, batu, gua dan bukit. Proses perancangan gubahan massa menggunakan karakteristik dari 4 unsur healing environment (Esther M.Sternberg (2009)) yakni berkerucut, bentuk tidak merata (naik turun), dan saling overlay.

\section{METODE}

Metode pengumpulan data menggunakan metode studi literatur, survey kuesioner, studi kasus, survey lapangan, buku, dan data dari internet. Tahap desain dimulai dari isu, literatur, kuesioner terhadap milenial terutama, studi kasus proyek serupa baik luar negri dan dalam negri, program, survey lokasi, analisa lokasi baik makro hingga mikro, gubahan massa dipadupadankan dengan analisa lokasi, metode program memanfaatkan teori dari Esther M.Sternberg dan hasil kuesioner, sistem bangunan dan detail.

Analisa lokasi dilakukan dengan pemetaan 2 dimensi dari makro, meso, hingga mikro. Dalam mendesain gubahan massa, pendekatan yang dilakukan adalah pendekatan hasil program, pendekatan analisa tapak, dan pendekatan terhadap teori Esther M.Sternberg.

\section{DISKUSI DAN HASIL}

\section{Analisa Tapak}

Pemilihan lokasi berdasarkan hasil korelasi dengan keterbukaan terhadap alam dan banyaknya kegiatan kebugaran. Kecamatan Tanjung Priok menjadi titik lokasi yang perlu memiliki fasilitas kebugaran, walaupun sudah memiliki banyak fasilitas olahraga. Lokasi tapak berada di jalur CFD (Car Free Day) dan memiliki unsur keterbukaan lokasi dengan alam dan unsur air. 

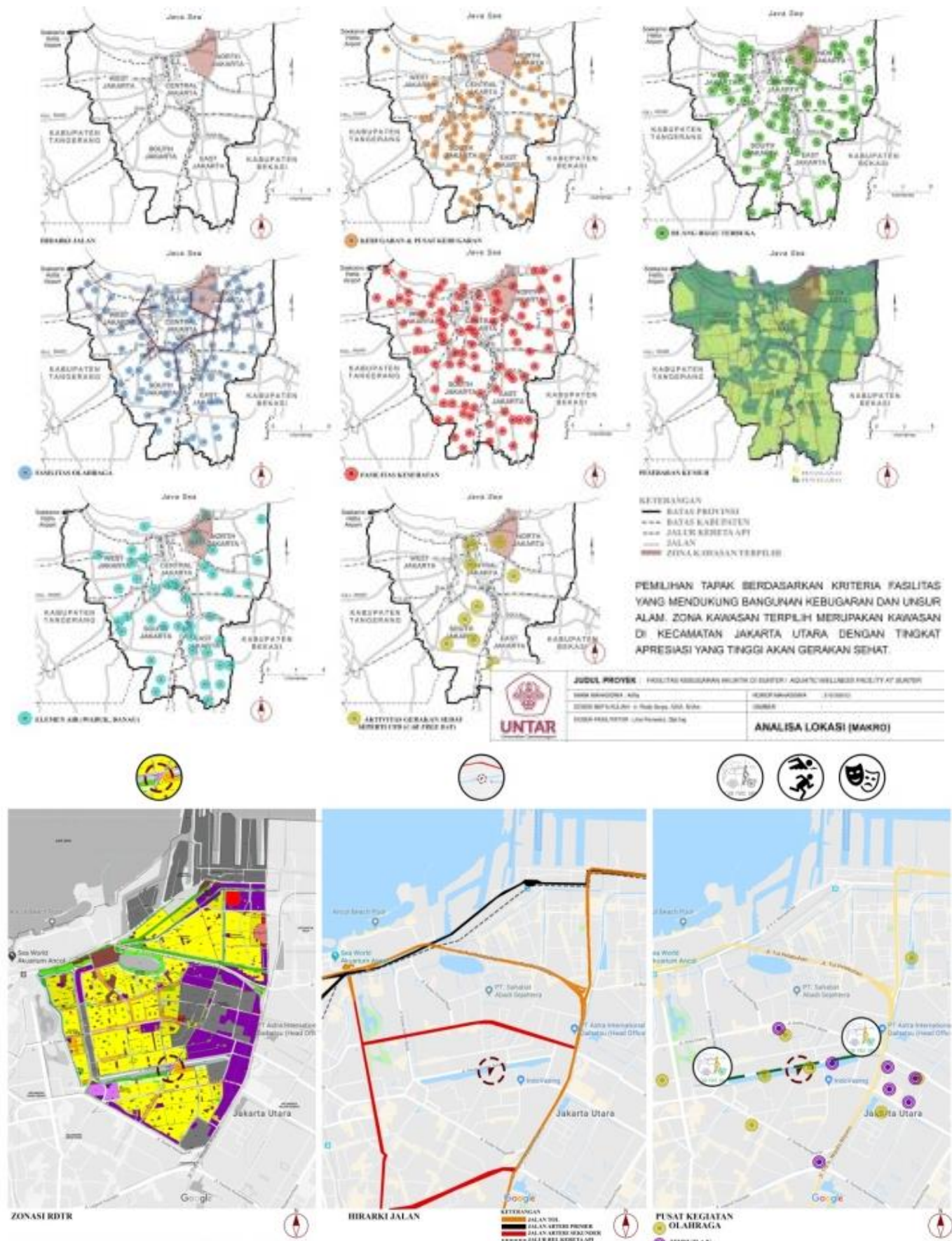

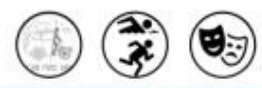
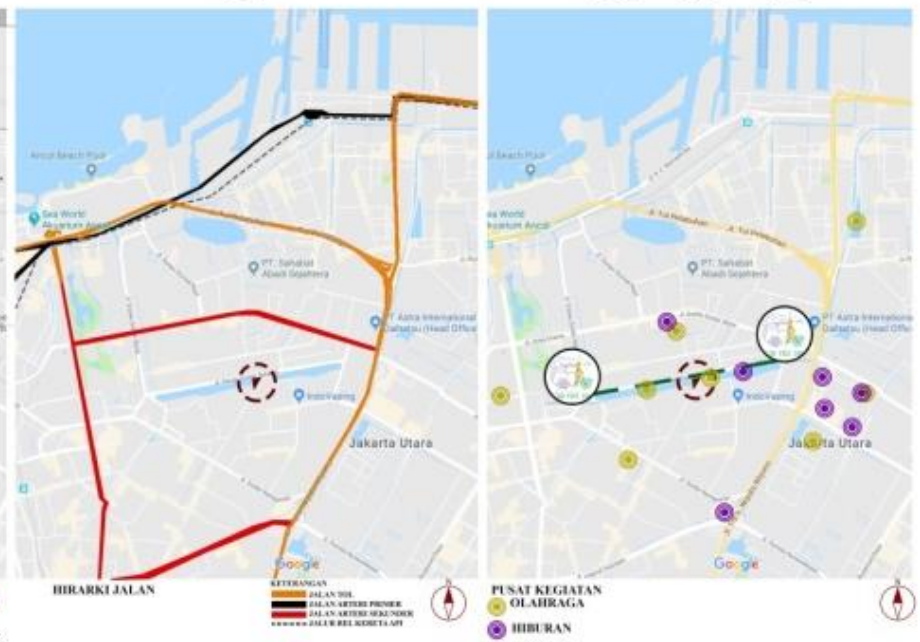

Gambar 3. Analisa Makro

Sumber: Penulis, 2019 


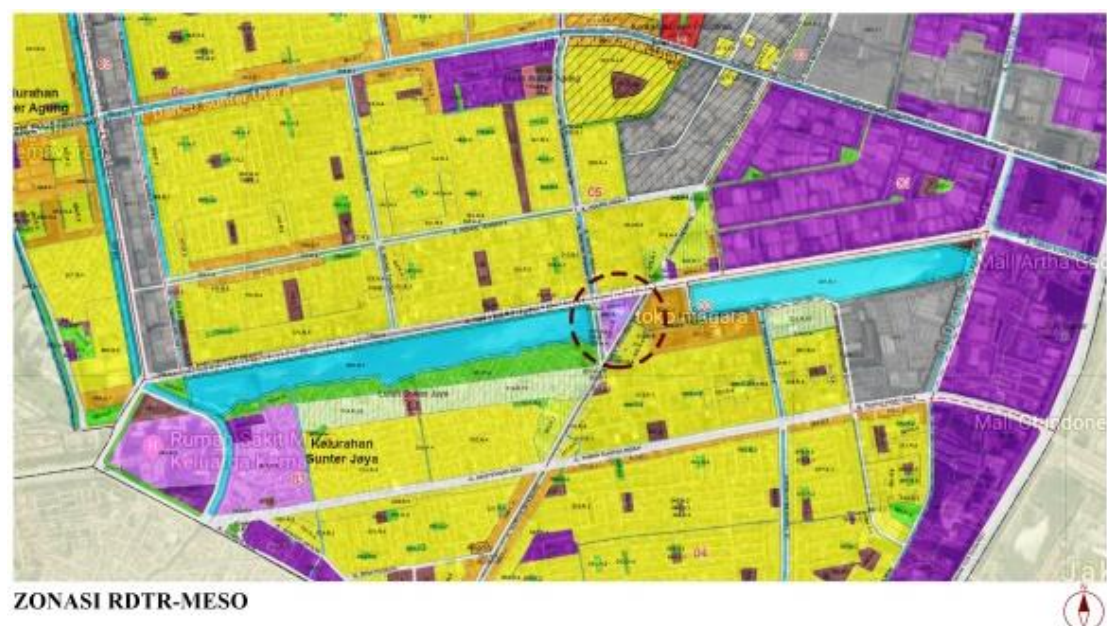

(2)

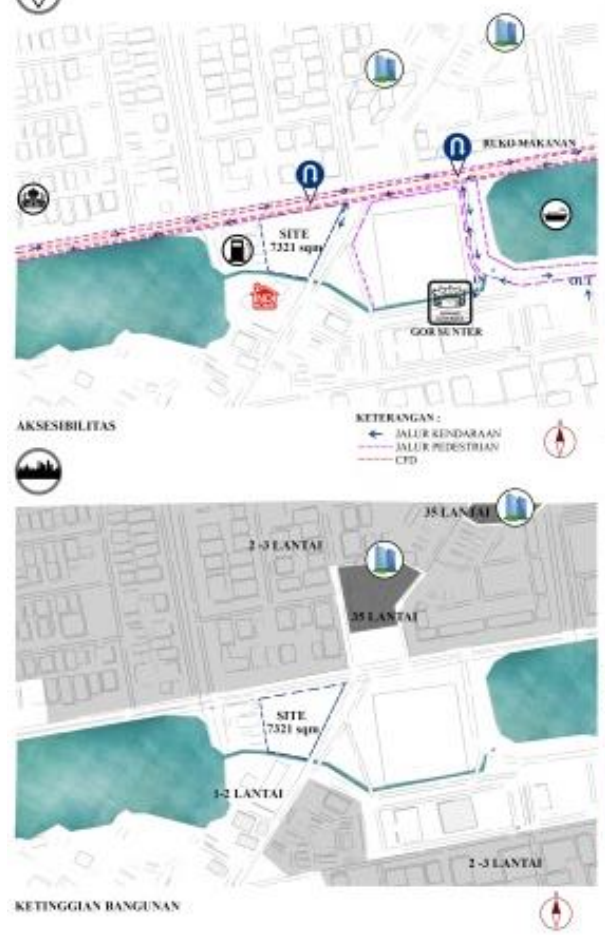

(-):

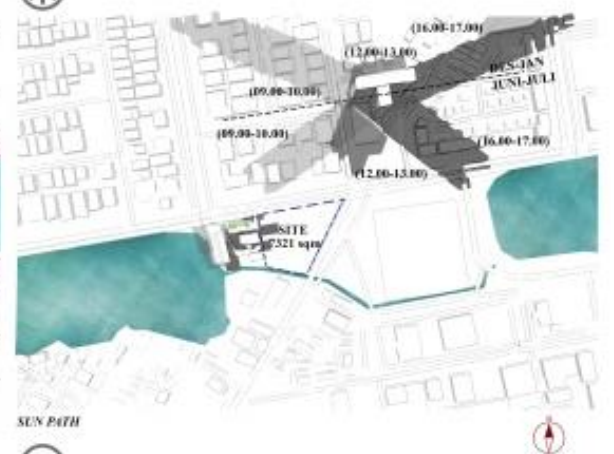

(2)

(11)

(1i)

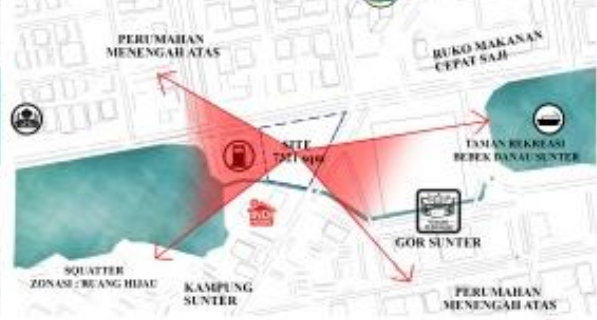

VEW \& KOWTEKS LVGKTISGNSEKTTAR
(4)

(4)

Gambar 4. Analisa Meso dan Mikro Sumber: Penulis, 2019

Tapak berada di zona perkantoran, perdagangan dan jasa kdb rendah, dikelilingi kompleks perumahan dan bangunan komersial. Berikut tabel zonasi RDTR Tapak:

Tabel 1. Zonasi RDTR Tapak

\begin{tabular}{|l|l|}
\hline Luas Tapak & $7321 \mathrm{~m}^{2}$ \\
\hline KDB 30\% & $2196 \mathrm{~m}^{2}$ \\
\hline KDH 45\% & $3294 \mathrm{~m}^{2}$ \\
\hline KLB 1.2 & $8785 \mathrm{~m}^{2}$ \\
\hline KB & 4 lantai \\
\hline KB & $2928 \mathrm{~m}^{2}$ \\
\hline KTB & $2928 \mathrm{~m}^{2}$ \\
\hline
\end{tabular}

Sumber: Perda DKI Jakarta No.1 Tahun 2014 
Danau sunter selatan merupakan kawasan wisata air masyarakat dengan berbagai kegiatan rekreasi yang menjadikan sirkulasi kendaraan dekat titik tersebut menjadi ramai. Tapak berada di antara 2 danau yang menjadi aset pemandangan dari fasilitas kebugaran akuatik. Proses perancangan gubahan massa memaksimalkan pemandangan dari danau sunter selatan dan waduk sunter barat yang merupakan titik pusat kegiatan di sepanjang jalan danau sunter selatan. Adanya aksis jalan yang jelas dari diagram ketinggian bangunan menjadi pertimbangan dalam meletakkan gubahan massa karena juga sesuai dengan hasil dari diagram sunpath.

\section{Program}

Berdasarkan hasil kuesioner yang dilakukan pada $62.7 \%$ responden wanita dan $37.3 \%$ responden pria milenial, mereka lebih cenderung menjaga asupan makanan. Meskipun dengan cara menjaga pola makan untuk tetap sehat, milenial lebih menyukai kegiatan fisik yang menyenangkan.

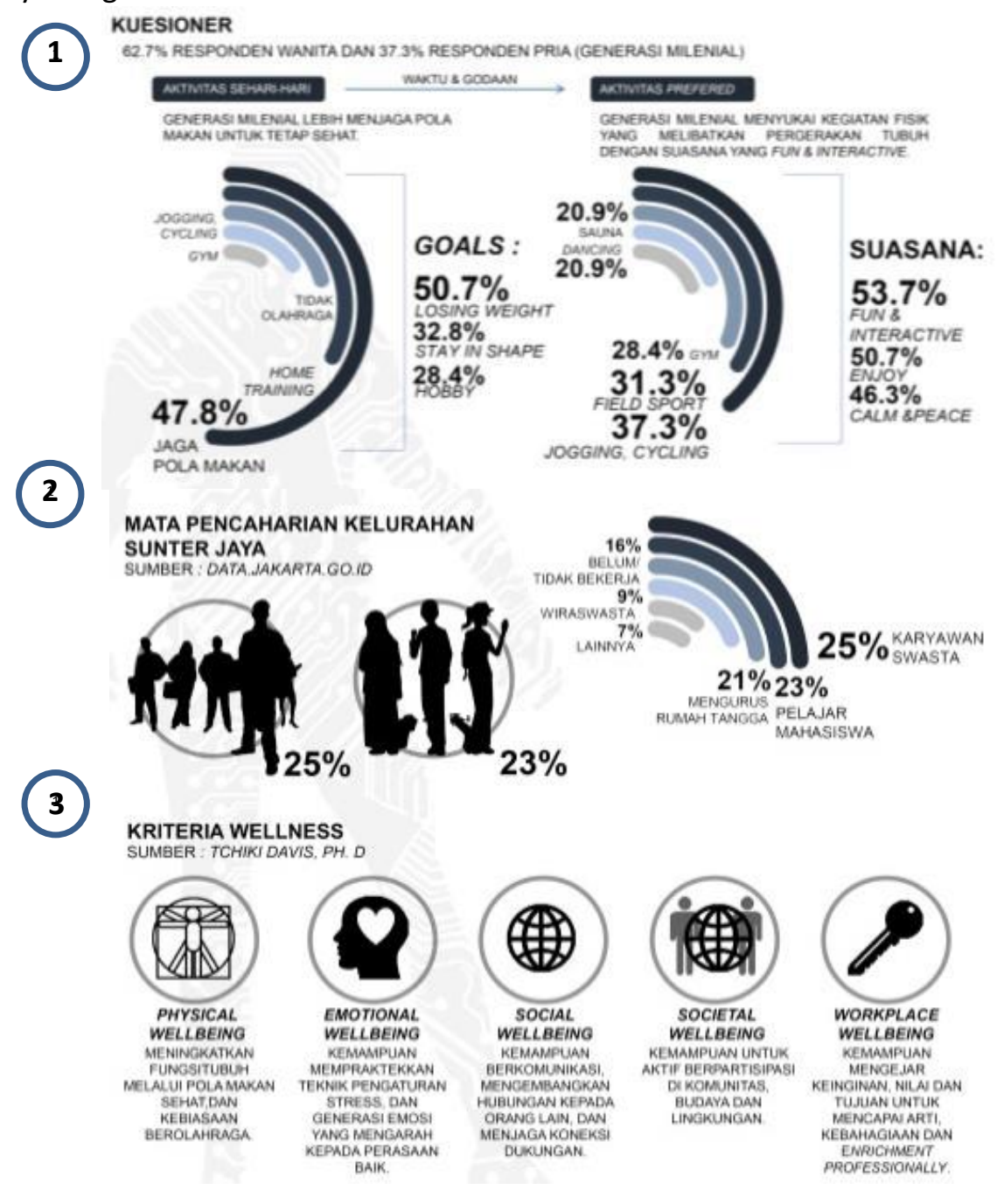

Gambar 5. Diagram Kuesioner, Pekerjaan dan Kriteria Wellness Sumber: Penulis, 2019; Datajakarta.go.id; Davis,2009

Dari ke-3 data di atas, data tersebut disesuaikan dengan program dan hasil kuesioner yakni unsur menarik dan menyenangkan. Program yang dihasilkan adalah sebagai berikut: 


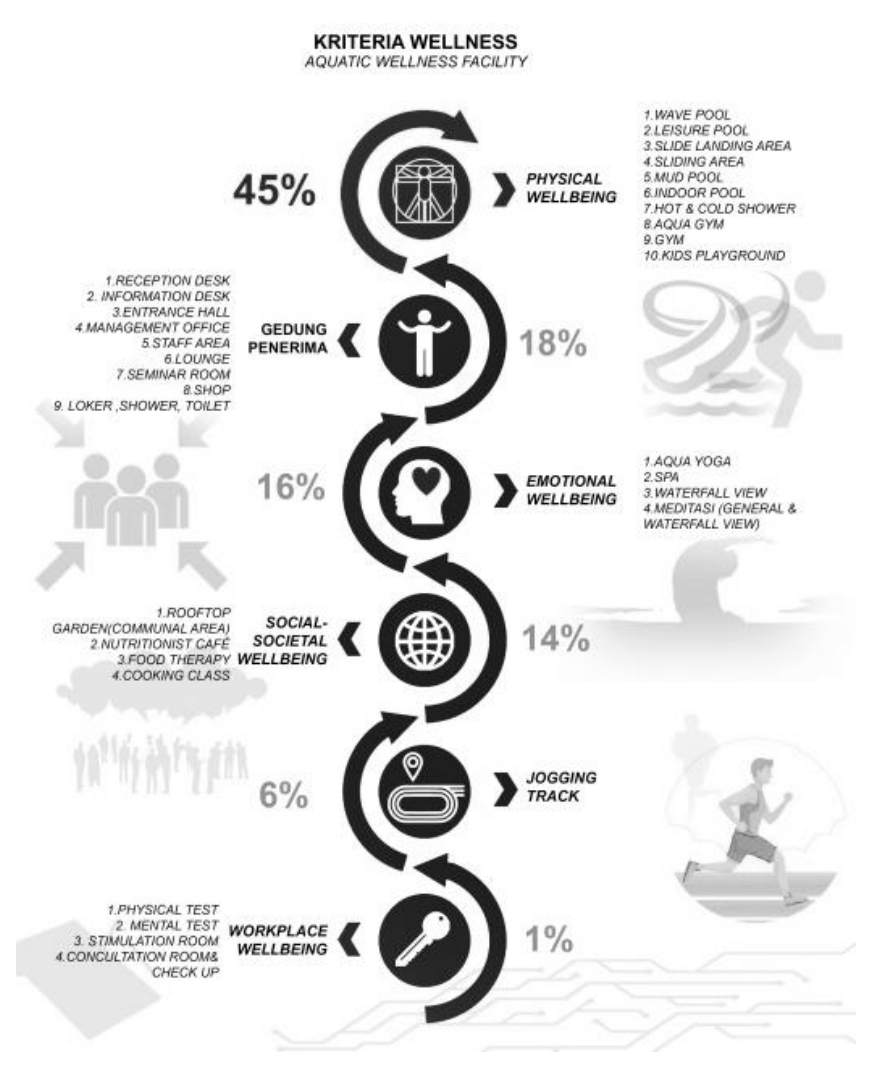

Gambar 6. Program Aquatic Wellness Facility

Sumber: Penulis, 2019

Dari diagram program di atas selain 4 unsur healing Environment (Esther M.Sternberg (2009)), perancangan ruang dalam memfokuskan kepada kondisi obyektif dan pengalaman subyektif untuk menghasilkan ruang yang positif.

\section{Konsep dan Bentuk Rancangan}

4 (empat) Karakter dari unsur healing environment dari (Esther M.Sternberg (2009)), ini menjadi pedoman dalam perancangan gubahan massa. Unsur healing environment dapat memberikan suasana relaksasi dengan atmosfer seperti di alam. Dari 4 karakter bentuk healing environment tersebut, didapat 3 karakteristik utama yakni berkerucut, bentuk tidak merata (naik turun), saling overlay. Dari tahap gubahan massa ini sudah tercapai kondisi obyektif dan pengalaman subyektif untuk menghasilkan ruang yang positif.

Berikut diagram gubahan massa berdasarkan peletakan analisa mikro:

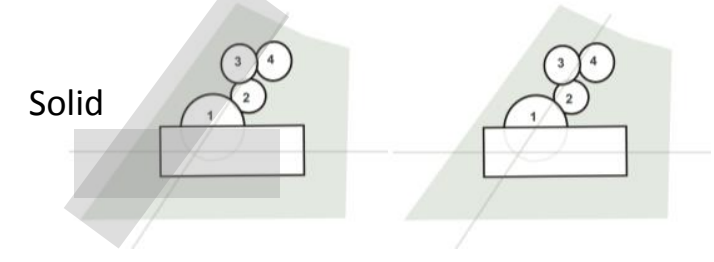

Gambar 7.Diagram Denah Gubahan Massa Sumber: Penulis, 2019

Area solid-void disesuaikan dengan hasil analisa mikro. 4 massa silinder tersebut mengikuti total jumlah dari unsur healing environment. Peletakan massa disesuaikan dengan aksis jalan dan arah matahari yang terjadi. Massa kotak menjadi area penerima utama bagi pengunjung yang disusul dengan 4 massa silinder ke arah selatan. 


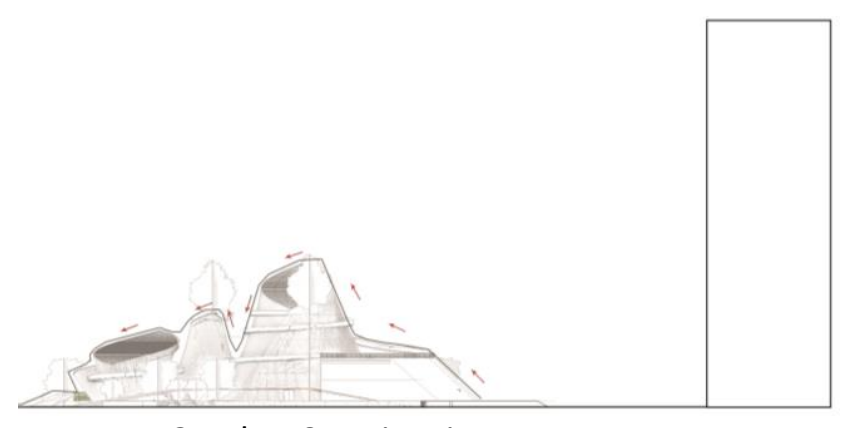

Gambar 8.Ketinggian Massa Bangunan

Sumber: Penulis, 2019

Konsep bentuk tidaklah memiliki ketinggian bangunan yang sama, ketinggian disesuaikan dengan karakteristik tersebut dan sifat dari akuatik (fleksible). Ketinggian bangunan tersebut disesuaikan dengan ketinggian bangunan sekitar.

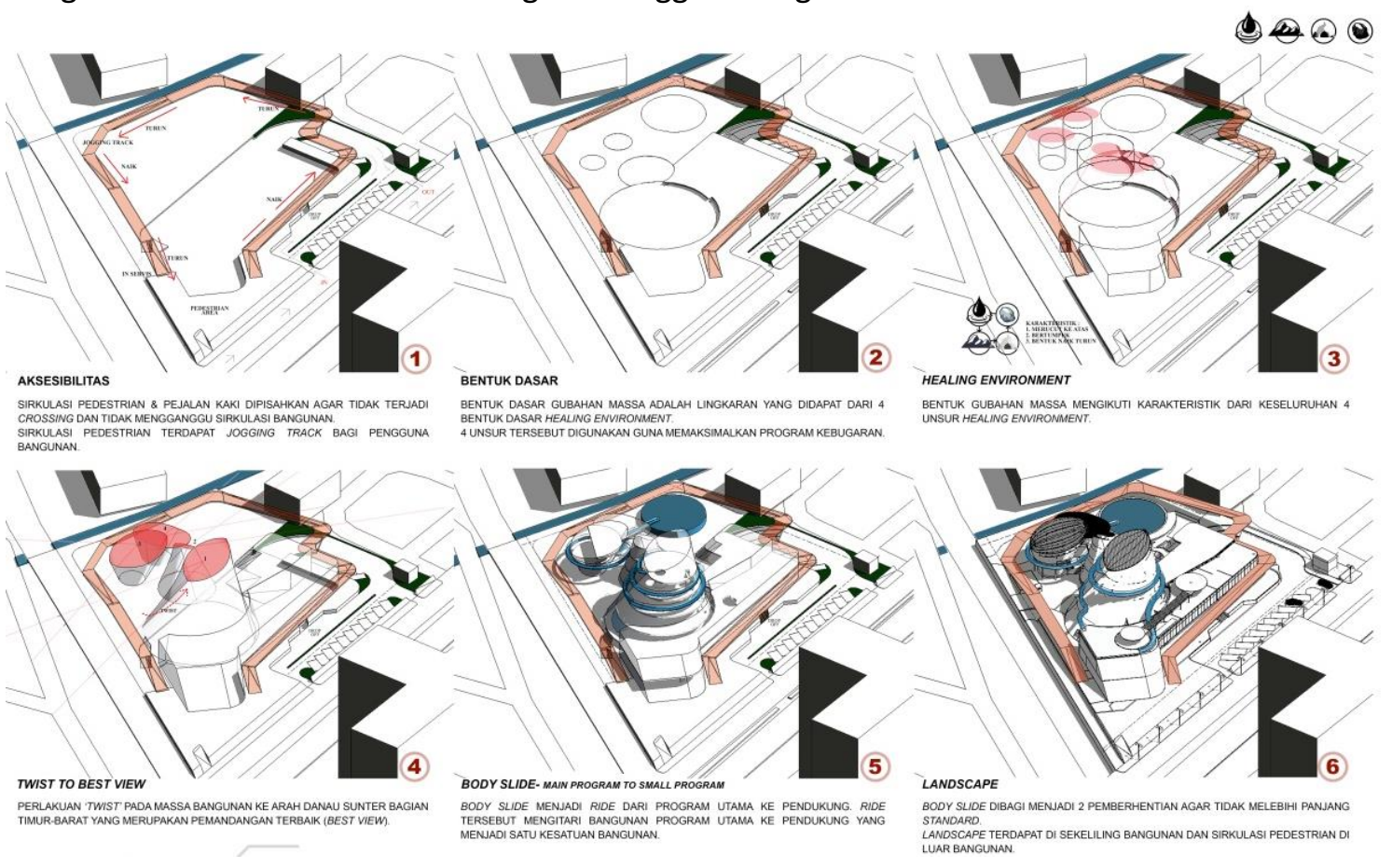

Gambar 9. Design Scheme Aquatic Wellness Facility

Sumber: Penulis, 2019

\section{KESIMPULAN DAN SARAN}

Kesimpulan :

a. Gaya hidup atau lifestyle kaum Milenial yang tidak sehat mempengaruhi pola perilaku kaum milenial menjadi tidak sehat, pasif (in-active), kondisi mental yang menurun, dan masih banyak lagi. Perilaku tersebut memberikan banyak dampak negatif terhadap kondisi kesehatan jasmani dan rohani kaum milenial.

b. 'Wellness' dapat memberikan pergeseran terhadap gaya hidup menjadi lebih sehat. Untuk memberikan pergeseran dan meningkatkan motivasi gaya hidup sehat tersebut, 'Wellness' dapat menghadirkan kesan menyenangkan dan menarik masyarakat terutama Milenial yakni Fasilitas Kebugaran Akuatik.

c. Unsur air memberikan relaksasi, ketenangan, dan seterusnya yang dapat memberikan lingkungan yang menyembuhkan. Fasilitas akuatik juga diberikan kesan rekreasi sehingga masyarakat maupun kaum Milenial melalui proses kebugaran dengan perasaan senang. Selain itu, meningkatnya permintaan pemasaran peralatan aqua gym 
menjadi salah satu trend kebugaran di kesejamanan ini.

d. Pemilihan lokasi berdasarkan hasil korelasi dengan keterbukaan terhadap alam dan banyaknya kegiatan kebugaran. Kecamatan Tanjung Priok menjadi titik lokasi yang tidak memiliki fasilitas kebugaran, namun memiliki fasilitas olahraga yang banyak, terdapat jalur CFD (Car Free Day) dan memiliki unsur keterbukaan lokasi dengan alam dan unsur air.

e. 4 Karakter dari unsur healing environment dari (Esther M.Sternberg (2009)), ini menjadi pedoman dalam perancangan gubahan massa. Unsur healing environment dapat memberikan suasana relaksasi dengan atmosfer seperti di alam. Dari 4 karakter bentuk healing environment tersebut, didapat 3 karakteristik utama yakni berkerucut, bentuk tidak merata (naik turun), saling overlay.

\section{Saran}

Program-program kebugaran dilaksanakan guna mencapai gaya hidup sehat, melihat dampak dari perilaku masyarakat terutama milenial yang terpengaruh oleh perkembangan teknologi. Proyek ini dapat bermanfaat bagi masyarakat untuk meningkatkan kualitas gaya hidup mereka menjadi lebih sehat.

\section{REFERENSI}

Centre For Strategic And International Studies. (2017). Ada apa dengan Milenial? Orientasi Sosial, Ekonomi dan Politik: Rilis dan Konferensi Pers "Survey Nasional CSIS 2017". Jakarta: Centre For Strategic And International Studies.

Davis, T. (2019). What Is Well-Being? Definition, Types, and Well-Being Skills. Diakses 16 Februari 2019, dari https://www.psychologytoday.com/us/blog/click-herehappiness/201901/what-is-well-being-definition-types-and-well-being-skills.

Global Wellness Institute. (2010). History of Wellness. Diakses 18 Februari 2019, dari https://globalwellnessinstitute.org/industry-research/history-of-wellness/.

Jakarta Open Data. (2018). Data Jumlah Penduduk Berdasarkan Pekerjaan Per Kelurahan tahun 2017 Diakses 13 Maret 2019, dari http://data.jakarta.go.id/dataset/jumlah-penduduk-dkijakarta-berdasarkan-pekerjaan/resource/1d4e7525-f975-4058-976c3563307126fe?inner_span=True.

Peraturan Daerah DKI Jakarta No.1 Tahun 2014 Rencana Detail Tata Ruang dan Peraturan Zonasi. 18 Februari 2014. Lembaran Daerah Provinsi Daerah Khusus Ibukota Jakarta Tahun 2014 Nomor 301. Jakarta.

Petermans A., Pohlmeyer Anna E. (2014). Designing and Planning the Built Environment for Human Well-being. Finlandia: Hasselt University, Delft University.

Prawira, A.E. (2018). 4 Masalah Kesehatan Ini Intai Generasi Milenial. Diakses 2 Januari 2019, dari https://www.liputan6.com/health/read/3518144/4-masalah-kesehatan-ini-intaigenerasi-milenial?source=search.

Putra, Y.S. (2016). Theoritical Review : Teori Perbedaan Generasi. Jakarta: STIE AMA Salatiga.

Sternberg, E. M. (2009). Healing Spaces. Cambridge: The Belknap Press of Harvard University Press.

Strohecker, J. (2015). A Brief History of Wellness. Diakses 15 Februari 2019, dari http://www.mywellnesstest.com.

Technavio. (2017). Global Aqua Gym Equipment Market 2017-2021. Diakses 18 Mei 2019, dari https://www.technavio.com/report/global-general-retail-goods-and-services-globalaqua-gym-equipment-market-2017-2021.

UNESCO. Sustainable Development Goals. Diakses 23 Januari 2019, dari https://www.un.org/sustainabledevelopment/sustainable-development-goals. 